\title{
Economic Transition in the City of Paterson, New Jersey (America's First Planned Industrial City): Causes, Impacts, and Urban Policy Implications
}

\author{
Thomas Y. Owusu \\ Department of Geography \& Urban Studies, William Paterson University, Wayne, NJ 07470, USA \\ Correspondence should be addressed to Thomas Y. Owusu; owusut@wpunj.edu
}

Received 7 May 2014; Revised 13 August 2014; Accepted 14 August 2014; Published 3 September 2014

Academic Editor: David Wong

Copyright @ 2014 Thomas Y. Owusu. This is an open access article distributed under the Creative Commons Attribution License, which permits unrestricted use, distribution, and reproduction in any medium, provided the original work is properly cited.

\begin{abstract}
This paper examines the dynamics of economic change in the City of Paterson, New Jersey, from the time of its founding in the late eighteenth century to 1990, with emphasis on the post-1945 era. Analysis shows that from the time of its founding to the first half of the twentieth century, Paterson experienced a period of economic growth followed by economic decline in the 1960s, characterized by major changes in its principal industries of cotton, locomotives, and silk. Economic growth in Paterson up to the early part of the twentieth century is attributable to several locational factors, including the availability of water resources, transportation, labor supply, and markets. Its decline in the post-1945 era is attributable to a combination of local, national, and global economic factors including periods of depression, labor discord, product substitution, decentralization of economic activities, and deindustrialization. Economic decline resulted in a high rate of unemployment, poverty, and urban decay. The most significant effort to reverse urban decline in the city is the urban enterprise zone (UEZ) program. The impacts of this program on economic growth in the city, however, remain inconclusive.
\end{abstract}

\section{Introduction}

Historically, American cities have been characterized by periodic changes in their economic base. Changes in the economic base of cities have been especially pronounced since 1945. The nature, scope, and outcome of these changes, however, have not been the same for every city. While some cities have experienced growth, others have declined or stagnated. These changes have caused differential urban growth and resulted in hierarchical changes in the US urban system. Economic change in American cities has resulted from the interplay of a range of local, regional, national, and global forces [1-7]. In the post-1945 period in particular, the forces of globalization, economic internationalization, mobility of capital, technological change, and changing international migration patterns have significantly shaped American cities [8].

One of the most dramatic economic changes in USA since the 1960s has been the decline of manufacturing employment [9]. This process, called by Bluestone and Harrison [10] as "deindustrialization," has been defined as "the systematic disinvestment in a nation's core manufacturing industries." Deindustrialization is generally attributed to a range of factors including economic globalization, the growing challenge to American global economic dominance, the ability of large corporations to shift capital from one area to another with growing ease, declining corporate profits, antiunion management, the avoidance of taxation and welfare responsibilities, shifting power relations between capital and labor, and policies of the federal government $[8,9]$. Urban economic restructuring itself, in response to these forces, has led to locational repercussions involving metropolitan growth, decline, or stagnation, as well as intrametropolitan plant and employment shifts involving primarily decentralization to suburban areas or nonmetropolitan locations. Economic transitions since the 1960s have altered the socioeconomic structure of American cities [3, 11]. The effects of deindustrialization on traditional industrial cities in USA include factory closure, urban fiscal crisis, unemployment, poverty, economic despair, and social decay. 
TABLE 1: Types and characteristics of metropolises in USA.

\begin{tabular}{|c|c|}
\hline Metropolis & Key trends/characteristics \\
\hline $\begin{array}{l}\text { Classic } \\
\text { deindustrializing } \\
\text { metropolis }\end{array}$ & $\begin{array}{l}\text { Loss of manufacturing employment } \\
\text { Disinvestment in manufacturing } \\
\text { Population decreases } \\
\text { Little immigration }\end{array}$ \\
\hline $\begin{array}{l}\text { Stable urban areas } \\
\text { in transition }\end{array}$ & $\begin{array}{l}\text { Decline in manufacturing } \\
\text { Population growth } \\
\text { More diverse economy } \\
\text { Gains in services and other } \\
\text { nonagricultural activities } \\
\end{array}$ \\
\hline $\begin{array}{l}\text { Slow growth urban } \\
\text { areas }\end{array}$ & $\begin{array}{l}\text { Manufacturing employment grew } \\
\text { quite quickly } \\
\text { Population grew at a much slower rate } \\
\text { High rate of growth in the services } \\
\text { sector }\end{array}$ \\
\hline $\begin{array}{l}\text { Growing service } \\
\text { centers }\end{array}$ & $\begin{array}{l}\text { Decline in manufacturing } \\
\text { Rapid population growth } \\
\text { Growth in services activities }\end{array}$ \\
\hline $\begin{array}{l}\text { New centers of } \\
\text { manufacturing }\end{array}$ & $\begin{array}{l}\text { Increase in population } \\
\text { Increase in manufacturing } \\
\text { employment } \\
\text { Increase in services sector activities }\end{array}$ \\
\hline
\end{tabular}

Source: Negrey and Zickel [12].

Economic change has led to the emergence of different types of cities in terms of their socioeconomic and demographic structure. Based on an analysis of changes in employment and population in 140 of the largest metropolitan areas in the United States between 1970 and 1990, Negrey and Zickel [12] identified five groups of metropolitan areas, namely, classic deindustrializing metropolises, stable urban areas in transition, slow-growth urban areas, growing service centers, and new manufacturing centers. The five categories of cities and their key characteristics are presented in Table 1. It is worth noting that most of the classic deindustrializing areas, stable urban areas in transition, and slow growth areas are located in the Northeast of Midwest. In contrast, the growing service centers and new centers of manufacturing are located primarily in the Southern or Western parts of USA.

The preceding observations highlight many theoretical and empirical questions about the dynamics of economic and demographic transition in US cities that warrant further examination: what is the nature and scope of these economic changes? What are the causes of these changes? What are the social, economic, and demographic outcomes and impacts of these changes? How do the underlying causes and the changes they effect vary from city to city? What are the urban policy implications of these impacts? This paper seeks to address these questions, using the City of Paterson, NJ, as a case study. Paterson provides a good case for studying economic and demographic transition in urban America, due to several reasons. First, it has the distinction of being the first planned industrial city in USA and, therefore, provides a good case for exploring and understanding the factors that shaped early industrial development in USA. Second, unlike other early industrial cities, economic decline in Paterson did not lead to population decline in the city. Third, since the 1960s, despite a period of economic decline, the city has experienced a continuous inflow of immigrants especially from Latin America, Asia, and Africa, leading to a change in the ethnic and racial composition of its population. Fourth, the city was designated as an urban enterprise zone in 1993 and has since been the recipient of several financial and economic incentives from the state aimed at promoting economic growth. Based on review of the literature and factors specific to Paterson, I hypothesize that (a) local and regional economic forces were just as important as national and global forces in causing economic decline in Paterson, (b) locational advantages, including proximity to New York City, and immigration contributed to Paterson's population stability, even during a period of economic decline, and (c) population stability primarily through continued flow of immigrants may have contributed to the persistence of economic decline in the city.

This paper focuses on the dynamics of economic change in the city from the time of its founding in the late eighteenth century until 1990, with emphasis on the post-1945 era. The analysis here deliberately stops in 1990, because, by this time, the main economic and demographic trends had bottomed out. Although emphasis is placed on the post-1945 period, key developments from the turn of the turn of the century are discussed to provide a historical context for understanding recent changes. Data for this study were drawn from various sources including US population censuses and from reports published by various city and state agencies and departments including The Greater Paterson Chamber of Commerce, Division of Economic Development, Division of Community Development, and the New Jersey Department of Labor.

\section{The Development and Growth of Paterson: A Historical Overview}

The City of Paterson is located within the highly urbanized New York-New Jersey Metropolitan Area. It is the third largest city in New Jersey, with a population of approximately 150,000 . Established in 1792, Paterson is recognized as the first planned industrial city in America. After the Revolutionary War of 1765, Alexander Hamilton (America's first Treasury Secretary) and his associates concluded that while the war had established the political independence of USA, there was the need to establish its independence from a commercial and manufacturing viewpoint. With this in mind they set out to lay the foundation of a system of domestic manufacturers. After examining several locations on the eastern cost of the country, including locations in Rhode Island, Connecticut, Massachusetts, Maryland, and Pennsylvania, the site that will late become known as Paterson was selected because, as is discussed in the following section, it offered more locational advantages than any of the other sites examined. In 1791, therefore, Hamilton and his associates formed the Society for Useful Manufacturers (SUM). A charter from the State Legislature exempted the company from taxation by the county and city and gave it the right to hold property, improve rivers, and build dams and canals. In July 4, 1792, the directors of SUM bought 700 acres of land above and below 
the Passaic Falls and proposed to build a mill and a dam to divert the Passaic River onto their property and return it to the river below the falls. Two days later, a six-square mile area surrounding the falls was created as a town and called Paterson, in honor of William Paterson, the then Governor of New Jersey and one of the framers of the US Constitution [13].

\subsection{Paterson's Locational Advantages. Paterson was selected} among several other sites because it was seen as offering more locational advantages for manufacturing than any of the other places considered. These advantages are derived from Paterson's site characteristics (the physical features that make up the immediate environment of a place's location) and situation characteristics (a place's relative location to other places and activities in the surrounding region). Paterson's site offered unique physical advantages for manufacturing including the availability of waterpower source, abundant natural resources, and a natural riverway. The Passaic Great Falls afforded waterpower not equaled with any of the states in the eastern portion of USA. In Paterson, the Passaic River plunges over the Great Falls which, at 77 feet high, is the second highest waterfall east of the Mississippi river, after Niagara Falls. Also the Passaic River, although not navigable, was excellent for silk dying purposes because of the unique quality of its water. In selecting this place, they also took into consideration the fact that artificial reservoirs of water may be easily formed at the different lakes and ponds on the headwaters of the streams tributary to the Passaic River, thereby keeping up the supply of water in dry seasons of the year. The location of manufacturing plants in the early period attests to the initial influence of the river.

Paterson's situation was an equally important locational consideration. The lack of accessible waterways was adequately compensated by good land transportation facilities, including access to many interstate roads. Its proximity to major markets in the Northeast, particularly its position between New York and Philadelphia, with their mercantile interests, and proximity to raw materials also contributed to Paterson's growth. Although it was near New York City (the largest market in USA), Paterson was far enough to avoid high metropolitan taxes and land prices. While lower taxes and land prices made Paterson a desirable place for industries, the relatively low cost of living attracted labor. The availability of labor in the city, in turn, attracted more manufacturing activities. Massive immigration to Paterson provided labor of all types, both skilled and unskilled. Most of the immigrants who came were an overflow of immigrants who came to New York City [14].

2.2. Paterson's Economic Base, Pre-1945. By 1900 Peterson was not only among the top five purely industrial cities in the nation, but also the fastest growing city on the East Coast [14]. From the time of its founding to the first half of the twentieth century, Paterson experienced a period of economic growth, followed by a period of decline, characterized by major changes in its principal industries, namely, cotton, locomotives, and silk. From 1792 to 1840 , the manufacture
TABle 2: Population growth in Paterson, 1810-1950.

\begin{tabular}{lcc}
\hline Census year & Population & Change (\%) \\
\hline 1810 & 2023 & - \\
1820 & 3338 & +65.0 \\
1830 & 7710 & +131.0 \\
1840 & 7596 & -1.5 \\
1850 & 11,341 & +49.0 \\
1860 & 19,588 & +22.7 \\
1870 & 33,579 & +71.4 \\
1880 & 51,031 & +52.0 \\
1890 & 78,347 & +53.5 \\
1900 & 105,171 & +34.2 \\
1910 & 125,600 & +19.4 \\
1920 & 135,875 & +8.2 \\
1930 & 138,513 & +1.9 \\
1940 & 139,656 & +0.8 \\
1950 & 139,135 & -0.4 \\
\hline
\end{tabular}

Source: Job and Bakal [16].

of cotton was the most important industrial activity in Paterson. However, it experienced a rapid decline during and immediately after the Civil War. During the same period, however, the iron and locomotive industries developed and prospered to become Paterson's leading industry. Indeed, by 1860 , the value of locomotive products alone had far surpassed that of cotton products.

What made Paterson the center of cotton manufacturing in New Jersey? An important factor was the abundance of water power developed by the SUM. No city in New Jersey had such supply, and, in the years before the adoption of stem power in textile manufacturing, water power was a prime requisite for any industrial operation. The next important industry established in the 1840s was that of silk [15]. The production of silk soon surpassed that of cotton, offering better wages and greater profit. Paterson dominated the silk industry in USA and became known as the Silk City of the world. By the end of the first decade of the 20th century, Paterson had 300 factories with over 18,000 workers, doing business worth about $\$ 40$ million a year. The early part of the twentieth century witnessed a heavy flux of mercantile establishments, clothiers, apparel shops, and various businesses to Paterson. This was a period of economic growth and prosperity in Paterson, as evidenced by the fact that its per capita debt was less than any other large city in New Jersey. As expected, economic growth was accompanied by population growth. As Table 2 shows, pre-1900 growth rates were very high, averaging over $60 \%$ per each census period, with the exception of a slight drop $(-1.5 \%)$ from 1830 to 1840 . Population growth continued after 1900, but at a declining rate Bakal and Job [16].

Industrial growth in Paterson in the second half of the nineteenth century was adversely affected by periods of depression and nationwide monetary failure. The 1857 depression, for instance, caused the closure of many factories in the city and led to the retrenchment of about 5,000 workers. 
Further economic difficulties were experienced around the turn of the century, notably the great silk strike of 1913, which was caused in part by wage cuts. The other event which contributed to the demise of the silk industry in Paterson was the introduction of artificial silk (or rayon) in 1910. Paterson failed to keep pace with developments in the textile field. As a result, Paterson lost its initial advantages to other regions, particularly Pennsylvania. The 1929 depression marked the final demise of the silk and locomotive industries and led to a high rate of unemployment. World War II brought full employment temporarily back to the city, as Curtiss-Wright became the War's largest airplane engine manufacturer, employing as many as 17,000 workers. At the end of the war in 1945, however, Curtiss-Wright moved out of Paterson, causing significant job losses [17].

\section{Economic Transition after 1945}

As in other parts of USA, the post-World War II era witnessed the establishment of a diversified economic base in North Jersey. At the same time, various manufacturing establishments either relocated from the region's core or were newly established. In Passaic County, most of this development took place on vacant land in places such as Clifton and Wayne, leaving the older City of Paterson faced with decline in manufacturing and in need of new economic base. Changes in Paterson's economic base in the post-World War II era are shown in Table 3. Textiles and apparel remained the most important industries in terms of their share of manufacturing employment, accounting for over $60 \%$ of manufacturing employment between 1950 and 1970. Paterson's regional and national dominance in these industries are reflected in the location quotient (source: [18]) presented in Table 3.

While still dominant in terms of its share of employment, textile mills manufacturing experienced an almost consistent decline in employment between 1950 and 1970. The decline was caused in part by a shift of this industry out of the Northeast region to other parts of the nation, particularly the South and even to other parts of the world partly in response to lower labor costs. In addition, there was a product substitution in the Northeast area in which the demand for the raw material textiles was replaced by a demand for the end-product derived from it, namely, apparel. As an industrial city, the loss of manufacturing jobs dealt a severe blow to the semiskilled and unskilled workforce.

\subsection{Decentralization of Economic Activities and Shifts in Eco-} nomic Base. After 1945, the suburbanization of manufacturing employment in metropolitan areas in the USA intensified. The dispersal of manufacturing employment occurred in response to a variety of push and pull factors pertaining to cities and suburbs, including space, taxes, congestion, pollution, cost of land, land-use controls, transportation need, and access to new infrastructure [7]. Until the early 1950s, manufacturing employment in core areas continued to grow, albeit at rates significantly below those of suburban areas. From the turn of the century, however, the share of metropolitan manufacturing employment held by central
TABLE 3: Employment in manufacturing industries, City of Paterson, 1950-1970.

\begin{tabular}{lcccccc}
\hline \multicolumn{7}{c}{ Location quotient } \\
& 1950 & 1960 & 1970 & 1950 & 1960 & 1970 \\
\hline Textile & 14,384 & 7,358 & 5,887 & 5.15 & 4.46 & 4.05 \\
Apparel & 7,133 & 5,546 & 6,085 & 2.67 & 2.52 & 2.98 \\
Fabric metal & 2,332 & 2384 & 2452 & 0.81 & 1.18 & 1.19 \\
Furniture & 505 & 745 & 594 & 0.62 & 1.32 & 0.87 \\
Paper & 810 & 878 & 702 & 0.75 & 0.82 & 0.67 \\
Printing & 952 & 1243 & 1236 & 0.57 & 0.77 & 0.75 \\
Chemical & 825 & 689 & 1203 & 0.58 & 0.47 & 0.77 \\
Rubber & 16 & 443 & 1209 & 0.02 & 0.65 & 1.40 \\
Leather & 603 & 664 & 707 & 0.69 & 1.02 & 1.48 \\
Stone/glass & 269 & 161 & 171 & 0.49 & 0.15 & 0.18 \\
Food & 1,301 & 1,386 & 1,694 & 0.33 & 0.43 & 0.64 \\
Primary metal & 546 & 800 & 518 & 0.10 & 0.36 & 0.34 \\
Machinery & 2313 & 2,173 & 2,401 & 0.78 & 0.82 & 0.82 \\
Electrical & 1352 & 2384 & 2177 & 0.61 & 0.91 & 0.86 \\
Instruments & 110 & 677 & 133 & 0.20 & 1.07 & 0.20 \\
Misc. small Gds & 942 & 1,276 & 760 & 0.06 & 1.83 & 1.02 \\
Total & $\mathbf{3 3 , 8 4 5}$ & $\mathbf{2 9 5 5 4}$ & $\mathbf{2 8 , 4 4 2}$ & & & \\
\hline Source: Paterson Dive & & & & &
\end{tabular}

Source: Paterson Division of Planning and Zoning, 1975 [18].

cities in USA started to decline, and growth rates were significantly below those of suburban areas. Suburban growth in producer services, particularly finance, insurance, and real estate (FIRE), have also overshadowed that of central cities in most metropolitan areas in the US since the mid-1970s [7].

Economic trends in Paterson mirrored the national and regional trends described above. Beginning in the 1960s, many manufacturing companies in Paterson left for suburban locations. The development of shopping malls in surrounding suburbs also forced the closure or relocation of many downtown retail businesses. The decentralization of economic activities in Paterson and other major cities in New Jersey is presented in Tables 4 and 5. Central city employment as a percentage of total employment in metropolitan areas declined between 1967 and 1972 in all sectors including manufacturing, retail, wholesale, and services. In Paterson, metropolitan area lost manufacturing employment $(-8.7 \%)$ but gained employment in the retail $(+25 \%)$, wholesale $(+21 \%)$, and services $(+50 \%)$ sectors. As Table 5 shows, these gains in employment occurred in the suburbs rather than in the cities, a further evidence of the decentralization of economic activities, noted earlier. In Paterson, there was a net gain in employment $(+3.8 \%)$ in all sectors combined, but an employment loss $(-13 \%)$ in the city and a gain $(12 \%)$ in the rest of the city.

In 1950, manufacturing employment in Paterson stood at 33,845 , accounting for $75 \%$ of private sector jobs. Between 1950 and 1975, the city lost $40 \%$ of its manufacturing jobs and more than half of the 1975 base between 1975 and 1997. The transportation, finance, retail, and trade sectors also showed significant declines between 1975 and 1997. The decrease in manufacturing employment in the city reflected 
TABLE 4: Central city employment as percentage of SMSA employment, selected New Jersey cities.

\begin{tabular}{lcccccccc}
\hline & \multicolumn{2}{c}{ Manufacturing } & \multicolumn{2}{c}{ Retail } & \multicolumn{2}{c}{ Wholesale } & \multicolumn{2}{c}{ Services } \\
& 1967 & 1972 & 1967 & 1972 & 1967 & 1972 & 1967 & 1972 \\
\hline Newark & 23 & 17 & 23 & 17 & 31 & 21 & 37 & 24 \\
Paterson & 34 & 31 & 32 & 20 & 36 & 32 & 37 & 30 \\
Jersey City & 25 & 24 & 41 & 40 & 48 & 37 & 54 & 50 \\
\hline Average & 41 & 38 & 44 & 36 & 56 & 45 & 58 & 51 \\
\hline
\end{tabular}

the experience of the region, the state, and USA; the loss in retail trade jobs reflected both competition from suburban shopping centers and demographic changes in Paterson. The job losses in transportation and finance were related to the city's declining relative position as a major commercial center, as well as consolidation in the banking industry throughout the region [19]. Although manufacturing has declined in Paterson, it remained one of the city's predominant economic sectors, accounting for $31 \%$ of all private sector jobs (Table 6). This compares with about 14\% in New Jersey and 18\% in USA. By the late 1990s, however, services (35\%) had overtaken manufacturing as the leading economic sector in Paterson [19].

3.2. The Impacts of Economic Transition. The economic and social impacts of economic decentralization in Paterson were significant. Among other things, it resulted in a high rate of unemployment, poverty, and urban decay. Table 7 shows the rate of poverty in selected cities in New Jersey. In 1970, Paterson was ranked 47th among the nation's poorest cities, but by 1980 it was fourth among the nation's cities with populations of 100,000 or more. The poverty rate for Paterson (25.2\%) was more than double the estimated national average of $12.5 \%$. Paterson ranked second (after Newark) among 147 largest US cities that were most distressed (based on unemployment rate, job change, per capita income, income change, and unemployment rate change). The pattern of New Jersey's cities exemplifies that of other northern and midwestern cities. In 1970, effective buying income per household in Paterson $(\$ 8,467)$ was the lowest in Passaic County, compared with $\$ 10,198$ for the county. The city also had a relatively high percentage of low-income households. In $1970,32.5 \%$ of the population earned less than $\$ 5,000$ per year compared with 23.\% for the county Lacz Associates [21]. Migration patterns were a major factor in these changes. After 1945, many northern and Midwestern cities lost substantial population. Thus the increases in poverty within these cities most likely reflect the migration of more affluent residents, which left behind poorer population.

This pattern of economic decline persisted throughout the 1980s. In 1990, per capita income in Paterson stood at $\$ 10,361$, more than $\$ 8,000$ below that in the rest of the county and the state. As Table 8 shows, among all Paterson residents in 1990, $18.5 \%$ had incomes below the federally defined poverty level, compared with $10.5 \%$ in the rest of the county and $7.6 \%$ in the state [19]. The economic predicament of Paterson's population described above may be explained in the context of the spatial mismatch hypothesis [22], which refers to the widening of the gap between population and employment opportunities, due to decentralization, with central city residents having far less access to suburban jobs [22]. When inner city residents do gain employment in suburban locations, they often have to travel longer distances, thus incurring greater costs [22].

3.3. Impact of Economic Transition on Paterson's Population. Economic change in Paterson contributed to not only the growth of its population, but also a change in the ethnic composition of the population. Despite a period of economic decline, Paterson's population has remained relatively stable from the turn of the century, with the exception of a slight drop in 1950 and in 1980 (see Table 9). This population stability may be attributable to several factors. First, it has remained a preferred destination for new immigrants especially from Latin America partly because of the channeling effects of chain migration. Second, Paterson's proximity to New York City offers accessibility and a relatively easy commute for residents. Third, Paterson offers more affordable housing options than what might otherwise be available in New York City. The relative population stability in Paterson stands in stark contrast to trends in many other older central cities in New Jersey in particular (see Table 10) and in the Northeast and Midwest in general. Since the 1960s, many of the large cities in New Jersey have experienced loss of population. During the 1980-1990 decade alone, for example, some of the nation's larger cities suffered double-digit percentage losses ranging as high as $25 \%$ [19].

Although the city' population has remained stable, the ethnic and racial composition has changed (Table 11). Up until 1950, the White population dominated, representing at least $95 \%$ of the total population. Between 1960 and 1990, however, the White percentage of the population declined sharply from $94 \%$ to $41 \%$. In contrast, the non-White population has increased dramatically since the early 1950s. Massive immigration from nontraditional sources, Latin America, Asia, Africa, Central and Eastern Europe, and the Middle East, has contributed to this ethnic diversity. In 1990, fiftysix different ethnic groups were represented in Paterson. An issue of particular interest here is the relationship between immigration and poverty levels in US cities. Some studies have suggested that increased immigration has contributed to a high rate of poverty in US cities [24]. The extent to which this applies to Paterson is not clear. However, it is worth noting that a high proportion of immigrants to Paterson have relatively low educational attainment and lack proficiency in the English language, factors known to significantly influence labor market opportunities and incomes of immigrants. The economic and demographic changes in Paterson described above-loss of industrial jobs, disinvestment, gains in services, and population growth primarily from increased immigration-seem to conform to the characteristics of stable urban areas in transition presented in Table 1. 
TABLE 5: Employment changes by major sector in selected distressed cities, 1967-1972 (in \%).

\begin{tabular}{|c|c|c|c|c|c|}
\hline & Manufacturing & Retail & Wholesale trade & Selected services & Total \\
\hline \multicolumn{6}{|l|}{ Newark } \\
\hline SMSA & -7.2 & -13.8 & +7.3 & +36.3 & +2.7 \\
\hline City & -30.9 & -18.5 & -26.8 & -7.2 & -24.9 \\
\hline (SMSA-city) & +0.04 & +23.6 & +23.0 & +43.8 & -12.0 \\
\hline \multicolumn{6}{|l|}{ Paterson } \\
\hline SMSA & -8.7 & +25.0 & +21.0 & +50.0 & +3.8 \\
\hline City & -16.8 & -23.9 & +7.9 & +20.0 & -13.2 \\
\hline (SMSA-city) & +4.4 & +48.3 & +29.0 & +68.6 & +12.7 \\
\hline \multicolumn{6}{|l|}{ Jersey City } \\
\hline SMSA & -11.5 & +3.7 & +17.6 & +17.6 & -8.5 \\
\hline City & -12.8 & +1.1 & +10.4 & +10.4 & -5.7 \\
\hline (SMSA-city) & -11.0 & +5.4 & +25.9 & +25.9 & -4.5 \\
\hline
\end{tabular}

TABle 6: Change in economic base in Paterson, 1970-1997.

\begin{tabular}{lcccc}
\hline & 1970 & 1980 & 1990 & 1997 \\
\hline Services & 10 & 28.5 & 31 & 35 \\
Retail & $\mathrm{n} / \mathrm{a}$ & 11.5 & 11 & 13 \\
Manufacturing & 54 & 43.7 & 36 & 31 \\
Wholesale & $\mathrm{n} / \mathrm{a}$ & 3.8 & 11 & 10 \\
Construction & 4.5 & 2.8 & 5 & 5 \\
FIRE & 4.5 & 3.3 & 3 & 2 \\
Comm/trans/utilities & 6.0 & 6.0 & 4 & 4 \\
\hline
\end{tabular}

Source: NJ Department of Labor and Demographic Research, various years [20].

TABLE 7: Poverty rate in 1970 and 1980 for selected cities in New Jersey.

\begin{tabular}{lcccc}
\hline \multicolumn{2}{r}{ Poverty rank } & & \multicolumn{2}{c}{$\begin{array}{c}\text { Percentage of persons } \\
\text { below poverty level }\end{array}$} \\
1980 & 1970 & & 1980 & 1970 \\
\hline 1 & 10 & Newark & $32.8 \%$ & $22.5 \%$ \\
4 & 47 & Paterson & $25.2 \%$ & $16.6 \%$ \\
17 & 82 & Jersey City & $21.2 \%$ & $13.7 \%$ \\
& & New Jersey & $9.5 \%$ & $8.1 \%$ \\
\hline
\end{tabular}

Source: US Bureau of the Census, various years [23].

\section{Addressing Urban Economic Decline}

The city government has implemented various policies and programs to reverse urban decline in Paterson and promote economic growth. Most of these programs have been aimed at economic development, particularly at the attraction and retention of businesses and industry to Paterson. Among other things, the city offers businesses free and professional help at everything from finding a location to getting permits and meeting bankers who want to lend local companies to finding the right store, factory, office, warehouse, or vacant land. The Paterson Restoration Corporation (PRC), a notfor-profit corporation, was established to foster business growth and job formation in the city. Through the PRC, companies have access to funding at below-market rates on loans up to $\$ 100,000$. In addition, the Paterson Small Business Development Center and the Paterson Economic Development Corporation (PEDC) provide technical and financial assistance for businesses [25].

4.1. Urban Enterprise Zone (UEZ) Program. Perhaps the most significant attempt at urban redevelopment in Paterson is its designation in 1993 as an Urban Enterprise Zone (UEZ). Since the mid-1980s, the UEZ program has been a hallmark for urban revitalization and a tool for urban economic growth and development in USA. Indeed Urban Enterprise Zones are a response to the depressed economic conditions present in many urban areas. More than thirty-six states have initiated enterprise zone programs to address urban problems [26]. In 1983, the New Jersey Legislature enacted the New Jersey Urban Enterprise Zone (UEZ) Act in an effort to help revitalize the state's economically distressed urban communities, defined as areas "of economic distress characterized by high unemployment, low investment of capital, blighted conditions, obsolete or abandoned industrial and commercial structures, and deteriorating tax bases." The legislation further stated that "it is the responsibility of government to provide a framework to encourage private capital investment in these areas, remove disincentives to investment, provide mechanisms for the coordination and cooperation of private and public agencies in restoring the economic viability and prosperity of these areas. Governor Kean, who signed the UEZ Act called it "the most significant step toward the economic revitalization of our cities in our state's history."

From 1984 through 1986, UEZs were designated in ten cities. In 1993, an amendment to the 1983 Act authorized the designation of ten additional UEZs, including Paterson. Today, there are a total of twenty-nine UEZs in New Jersey, and all of the state's major cities are part of the program. All businesses that qualify for UEZ program participation are eligible to receive incentives that reduce costs of operating in the zones. These incentives include qualified retailers charging $50 \%$ on New Jersey sales tax on "in person purchases" ( $3 \%$ which is half of the New Jersey sales tax rate of $6 \%$ ); sales tax exemptions for materials and for tangible personal 
TABLE 8: Per capita income and percentage of population living below poverty level selected areas, 1990.

\begin{tabular}{lcccc}
\hline & \multicolumn{2}{c}{$\begin{array}{c}\text { Income per capita } \\
\text { Compared to New Jersey }\end{array}$} & $\begin{array}{c}\text { Population below poverty line } \\
\text { Compared to New Jersey }\end{array}$ \\
\hline Paterson & $\$ 10,361$ & 0.55 & $18.5 \%$ & 2.43 \\
Rest of Passaic County & $\$ 18,544$ & 0.99 & $10.0 \%$ & 1.32 \\
Northern New Jersey & $\$ 19,510$ & 1.04 & $8.7 \%$ & 1.15 \\
New Jersey & $\$ 18,714$ & & $7.6 \%$ & \\
\hline
\end{tabular}

Source: Urbanomics, 2000 [19].

TABLE 9: Paterson's population, 1900-1990.

\begin{tabular}{lcc}
\hline Census year & Population & Change (\%) \\
\hline 1900 & 105,171 & 20.4 \\
1910 & 125,600 & 19.4 \\
1920 & 135,875 & 8.2 \\
1930 & 138,513 & 1.9 \\
1940 & 139,656 & 0.8 \\
1950 & 139,135 & -0.4 \\
1960 & 141,131 & 1.4 \\
1970 & 144,676 & 2.5 \\
1980 & 138,970 & -4.8 \\
1990 & 140,891 & 7.6 \\
\hline
\end{tabular}

Source: Bakal and Job [16].

TABLE 10: Population changes in NJ's six major cities (in thousands and $\%$ of change), 1960-1990.

\begin{tabular}{lcccc}
\hline & 1960 & 1970 & 1980 & 1990 \\
\hline Newark & 405 & $382(-5.7)$ & $329(-13.9)$ & $275(-16.4)$ \\
Jersey City & 276 & $260(-5.8)$ & $224(-13.8)$ & $229(+2.2)$ \\
Paterson & 144 & $145(3.5 \%)$ & $138(-4.8)$ & $141(2.2)$ \\
Elizabeth & 108 & $113(4.6 \%)$ & $106(-6.2)$ & $110(3.8)$ \\
Trenton & 114 & $105(-7.9)$ & $92(-12.4)$ & $89(-3.3)$ \\
Camden & 17 & $103(-12.0)$ & $85(-17.5)$ & $87(2.4)$ \\
\hline
\end{tabular}

Source: Bakal and Job [16].

TABle 11: Ethnic change in Paterson, 1900-1990.

\begin{tabular}{lccccc}
\hline & White & $\%$ & Non-White & $\%$ & Total \\
\hline 1900 & 103,859 & 98.8 & 1,313 & 1.2 & 105,171 \\
1910 & 123,969 & 98.7 & 1,631 & 1.3 & 125,600 \\
1920 & 134,254 & 98.8 & 1,621 & 1.2 & 135,875 \\
1930 & 135,424 & 97.8 & 3,089 & 2.2 & 138,513 \\
1940 & 135,300 & 96.9 & 4,353 & 3.1 & 139,656 \\
1950 & 130,845 & 94.0 & 8,290 & 5.9 & 139,135 \\
1960 & 122,310 & 85.1 & 21,353 & 14.8 & 143,663 \\
1970 & 103,777 & 71.6 & 41,047 & 27.4 & 144,824 \\
1980 & 83,750 & 56.1 & 65,419 & 46.4 & 149,169 \\
1990 & 57,977 & 41.1 & 82,912 & 58.8 & 140,889 \\
\hline
\end{tabular}

Source: US Bureau of the Census, various years [23].

property; a one-time corporation tax credit of $\$ 1,500$ for the full-time hiring of residents of the city where a zone is located who have been unemployed or dependent on public assistance for at least 90 days; a corporation tax credit of $\$ 500$ for hiring a resident within the zone, within another zone, or within a qualifying municipality; subsidized unemployment insurance costs for new employees whose gross monthly income is not more than $\$ 1,500$. In addition, an eligible firm may receive priority for financial assistance from the New Jersey Local Development Financing Fund and Job Training Program. The 3\% sales tax that is collected by UEZ retailers is deposited in the Zone Assistance Fund (ZAF). Revenues from the ZAF are returned to each UEZ in proportion to total sales tax revenues collected by qualified retail businesses in that zone "for the purpose of assisting qualifying municipalities in which enterprise zones are designated in undertaking public improvements and in upgrading eligible municipal services in designated enterprise zones" [27].

4.1.1. The Impact of Urban Enterprise Zones. Over thirty years after its inception, a number of key questions have been raised about these zones: have enterprise zones experienced economic growth? What incentives are responsible for this growth? Have the socioeconomic conditions of local enterprise zone residents improved? Are incentives effective in terms of employment creation and cost effectiveness? Paterson was designated as an urban enterprise zone in 1993. The zone encompasses $30 \%$ of the land mass of the city [28]. To date, no comprehensive study of Paterson's UEZ has been undertaken; therefore, it is it difficult to assess the program's impacts. Information gathered from different sources, however, provide some insights into the performance of the program. The Paterson UEZ has 405 certified businesses, with 9,371 full-time employees and average annual revenue of $\$ 2.8$ million. Since it was established, over 100 companies have relocated to Paterson, creating 3,560 jobs. According to the city's UEZ website, since Paterson won UEZ designation, the city has collected some $\$ 41$ million in tax revenue for a number of revitalization projects and funded 64 economic development projects. The presence of the zone helped persuade Center City Partners to build City Center Mall which brought 600 jobs to the city. Business improvement grants under the program have contributed to improvements in the appearance of facades, sidewalks, and landscapes, funding the installation of video surveillance camera to enhance security and safety, and building bus shelters, decorative lights, and bike racks.

Two comprehensive studies of the UEZ program in New Jersey provide additional insights into the impacts 
of the program. In 1998, the Response Analysis Corporation conducted an independent evaluation of the program. The evaluation, which covered 20 UEZs in the program prior to 1996, including Paterson, had a generally favorable impression of the performance of the UEZs, including the following. In addition to investing in New Jersey's distressed urban communities, companies participating in the UEZ program also created jobs and generated state and local tax revenues. Part of the UEZ program's job impact was achieved by encouraging firms that were relocating to consider and choose locations in the state's urban areas. From 1984 to 1997, UEZ companies in the 20 zones invested over $\$ 4$ billion in their zone businesses and created over 46,000 new jobs in the 20 zones. A substantial proportion of the jobs created in the UEZs came from start-up and move-up companies. Startup firms generated $26 \%$ of all new UEZs jobs among active businesses and move-ins were responsible for generating $33 \%$ of all new UEZ jobs. Overall, UEZ incentives were cited as the only, primary, or secondary factor in expansion, relocation, or start-up decisions for businesses that created $74 \%$ of all new jobs in 20 UEZs studied. The study found that the UEZ program helped to restore economic viability in distressed cities and helped to keep property rates down. The study found that from 1994 to $1996,56 \%$ of the new employees hired by UEZ businesses were residents of the UEZ communities studied. On the average, the employment grew in the UEZ municipalities at a faster rate after the program implementation compared to other cities that met the same district criteria for program participation, but not selected. By using ZAF monies to make public improvements and to upgrade municipal services, UEZ municipalities saved over \$144 million in local property taxes from 1987 to 1997 [27].

Findings from a more recent comprehensive study of the performance of all UEZs in New Jersey including Paterson, from 2002 to 2008, however, have raised questions about the effectiveness of the program and even recommended its termination as it currently functions, and its replacement with a new place-based community and economic development program. The report indicated that, since 1983, UEZs have attracted private investment estimated at $\$ 32$ billion and generated 133,000 full-time jobs. In addition, since the program started, 30,000 businesses have benefited from it, and sales tax revenues generated by UEZ businesses have led to 2,620 economic development projects [29].

Although the New Jersey UEZ program has some tangible signs of success, the report criticized it on several grounds. The principal findings of the study are as follows: (a) only $20 \%$ of eligible businesses participated in the program, and $\$ 238$ million in zone assistance funds were unspent from 2002 to 2008; (b) the zones generated 83 cents in "ripple effect" economic activity for every $\$ 1$ in forgone tax revenue, and another 8 cents in state and local revenue; (c) over $\$ 34$ million which accrued to Zone Assistance Funds are left unspent each year; (d) less than $5 \%$ of investment is spent for construction/renovation; (e) increase in overall employment in all businesses in UEZs, but largely due to factors other than UEZ investment; (f) net loss of over 2,200 jobs in participating UEZ businesses; ( $g$ ) relative decrease in household income, widening gap between UEZ and New Jersey household incomes; (h) increase in housing vacancy rate; relative decrease in home values, widening gap between UEZ and New Jersey home values; (i) there is no documentation of private investment by UEZ businesses, and the program offers no certain quantifiable results relative to the original legislative intent for local businesses and expansion as well as job creation; (j) there is a striking gap between UEZ businesses' job losses and New Jersey's employment gain as a whole; $(\mathrm{k})$ persistent blight remains in many areas throughout New Jersey. The report noted that while other states have streamlined their program, the New Jersey UEZ remained bureaucratically cumbersome and costly to operate, with results that are inconsistent and hard to quantify. For example, it took 135 people statewide to run 32 zones; across the border in Pennsylvania, 27 people run 23 zones [30].

The primary issue is whether the program stimulates local economies enough to justify the lower tax rate. Critics suggest that the benefits go to companies that would have moved into urban areas anyway. A review of the program by the Star Ledger newspaper showed that spending has deviated widely from the initial UEZ plan, expanding the definition of economic development beyond what was envisioned in 1983. The review showed that local officials often used UEZ dollars as just another form of municipal aid, paying for everything from firefighter salaries to buying jaws of life, things that may have benefited the cities but did not necessarily help the zones themselves. The sales tax benefit has spurred many, perhaps most, of the zones to concentrate on retail business $(80 \%$ in Jersey City). While this generates the funds for the ZAF, it generates service jobs, frequently low wage, and low mobility as opposed to high wage industrial or professional positions. The zones were designed to end and cities were supposed to graduate from the program after downtowns improved, but, in nearly 30 years, none of the cities has [31].

\section{Conclusion}

This paper has examined the dynamics of economic change in the City of Paterson, with emphasis on the post-1945 era. The analysis has shown that, from the time of its founding to the first half of the twentieth century, Paterson experienced a period of economic growth followed by economic decline, characterized by major changes in its principal industries. Economic growth in Paterson up to the early part of the twentieth century is attributable to several locational factors, including the availability of water resources, transportation, labor supply, and markets. Its decline in the post-1945 era is attributable to a combination of local, national, and global economic factors including periods of depression, labor discord, product substitution, decentralization of economic activities, and deindustrialization. Economic decline resulted in a high rate of unemployment, poverty, and urban decay. However, unlike other urban areas, economic decline did not lead to population decline. Indeed the population of Paterson has remained relatively stable. This stability is attributable to the impact of immigration from Latin America. Paterson's 
proximity to New York City provides accessibility for commuters. In addition, it is an appealing location especially for new immigrants because it offers more affordable housing options than New York City.

To address economic decline in the city, Paterson was designated as an urban enterprise zone in 1993. Evaluation of the impact of this program from rather limited information yields inconclusive results. On the one hand, the program has provided much needed economic boost to the city. The zone has been able to attract firms and jobs; it has more companies and jobs now than it did when it was designated. Like other UEZs, it also performed better than the economic context within which it was located. The enterprise zone may also have helped adjacent areas by employing their residents or producing multiplier effects from the companies locating or expanding within the zone. In addition, the program has contributed to improvements in the appearance of facades, sidewalks, and landscapes and enhanced security and safety. A recent and more comprehensive study, however, shows that the New Jersey UEZs including Paterson have not achieved their intended results in terms of economic growth, job creation, unemployment and poverty reduction, economic investment, and reduction in urban blight. The findings and recommendations of this study may be used to revamp the UEZ program to make it more effective. Perhaps it is time for Paterson and other distressed cities in New Jersey to consider implementing different urban and economic development programs.

\section{Conflict of Interests}

The author declares that there is no conflict of interests regarding the publication of this paper.

\section{References}

[1] L. Benton-Short, Ed., Cities of North America: Contemporary Challenges in U.S. and Canadian Cities, Rowman and Littlefield, Lanham, Md, USA, 2014.

[2] M. Abrahamson, Global Cities, Oxford University Press, New York, NY, USA, 2004.

[3] T. Rieniets, "Shrinking cities: causes and effects of urban population losses in the twentieth century," Nature and Culture, vol. 4, no. 3, pp. 231-254, 2009.

[4] D. Rigby, Urban and Regional Structuring in the Second Half of the Twentieth Century, edited by J. Agnew, J. M. Smith, American Space/American Place, New York, NY, USA, 2002.

[5] P. L. Knox, "Globalization and urban change," Urban Geography, vol. 17, no. 1, pp. 115-117, 1996.

[6] B. Warf and R. Erickson, "Introduction: globalization and the U.S. city system,” Urban Geography, vol. 17, no. 1, pp. 1-4, 1996.

[7] E. Wyly, N. J. Glickman, and M. L. Lahr, "The top 10 list of things to know about American cities," Cityscape: A Journal of Policy Development and Research, vol. 3, no. 3, 27 pages, 1998.

[8] D. Wilson and M. Anderson, "Urban economic restructuring," in Cities of North America: Contemporary Challenges in U.S. and Canadian Cities, L. Benton-Short, Ed., Roman and Littlefield, Lanham, Md, USA, 2014.
[9] D. Brady and R. Denniston, "Economic globalization, industrialization and deindustrialization in affluent democracies," Social Forces, vol. 85, no. 1, pp. 297-329, 2006.

[10] B. Bluestone and B. Harrison, Deindustrialization in America, Basic Books, New York, NY, USA, 1982.

[11] W. J. Wilson, When Work Disappears: The World of the New Urban Poor, Vintage, 1996.

[12] C. Negrey and M. B. Zickel, "Industrial shifts and uneven development: patterns of growth and decline in US metropolitan areas," Urban Affairs Quarterly, vol. 30, no. 1, pp. 27-47, 1994.

[13] J. A. Carpenter, The Industrial Development of Paterson: 17921913, Columbia University, New York, NY, USA, 1947, The Industrial Development of Paterson,.

[14] C. Norwood, About Paterson: The Making and Unmaking of an American City, Saturday Review Press, New York, NY, USA, 1974.

[15] C. Shiner, Paterson, New Jersey: Its Advantages for Manufacturing and Residence, The Printing and Publishing, Paterson, NJ, USA, 1890

[16] M. Bakal and K. Job, A Study of Paterson's Population Research Paper, Wayne, New Jersey, NJ, USA, 1990.

[17] Senior Class of the State Normal School of Paterson; New Jersey, Hudson Dispatch Printer, Union City, NJ, USA, 1932.

[18] Paterson Division of Planning and Zoning, Employment Trends in Industry, Paterson and Environs, 1950-1972, Paterson Division of Planning and Zoning, Paterson, NJ, USA, 1975.

[19] Urbanomics, City of Paterson Urban Enterprise Zone Strategic Economic Plan, Urbanomics, Paterson, NJ, USA, 2000.

[20] New Jersey Department of Labor and Demographic Research Economic and Demographic Report Trenton: New Jersey, various years.

[21] Lacz Associates, Community Renewal Program, City of Paterson: Economic Base Study, Paterson, NJ, USA, 1975.

[22] H. J. Holzer, "The spatial mismatch hypothesis: what has the evidence shown?” Urban Studies, vol. 28, no. 1, pp. 105-122, 1991.

[23] U.S. Bureau of the Census, "Census of Population and Housing," Washington, DC, USA, U.S. Government Printing Office, various years.

[24] S. Cammarato, Importing Poverty, Center of Migration Studies, Washington, DC, USA, 2000.

[25] City of Paterson, Paterson: Special Advertising Supplement, Office of the Mayor, Paterson, NJ, USA, 1998.

[26] F. D. Beck, Do State-Designated Enterprise Zones Work? Illinois State University, Chicago, Ill, USA, 1997.

[27] Analysis Response Corporation, New Jersey Urban Enterprise Zone Fiscal Impact Study, Response Analysis Corporation, Princeton, NJ, USA, 1998.

[28] P. Carney and A. Pereira, National Survey of Urban Economic and Community Development Models.

[29] J. Renshaw, NJ Consultant Call for Elimination of Urban enterprise Zone Program, 2011.

[30] Delta Development Corp, New Jersey Urban enterprise Zone Program Assessment 2011 Trenton: NJEDA State of New Jersey Department of Community Affairs, 2011.

[31] C. O'Dea, "Restoring the State's Urban Enterprise Zone Program," NJ Spotlight News, 2011. 

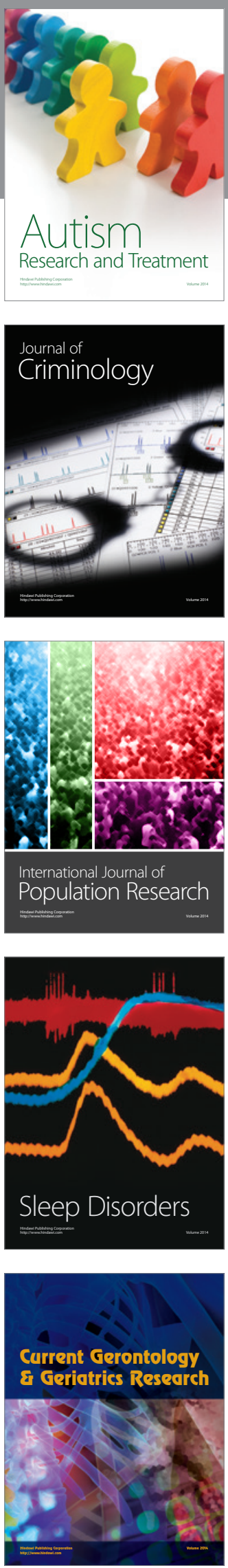
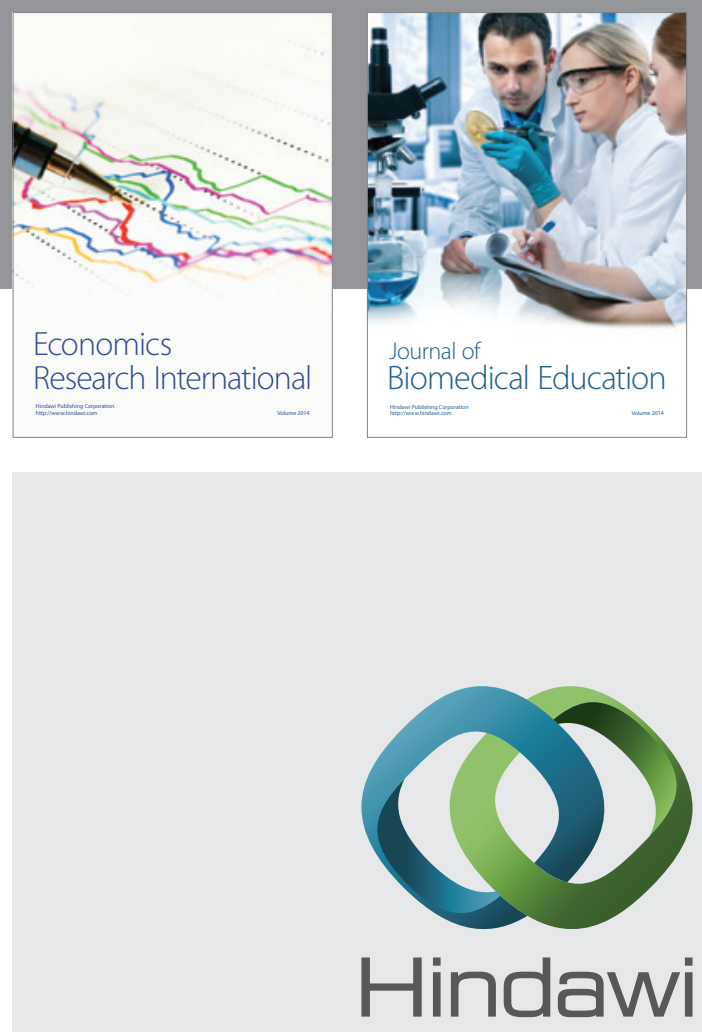

Submit your manuscripts at

http://www.hindawi.com
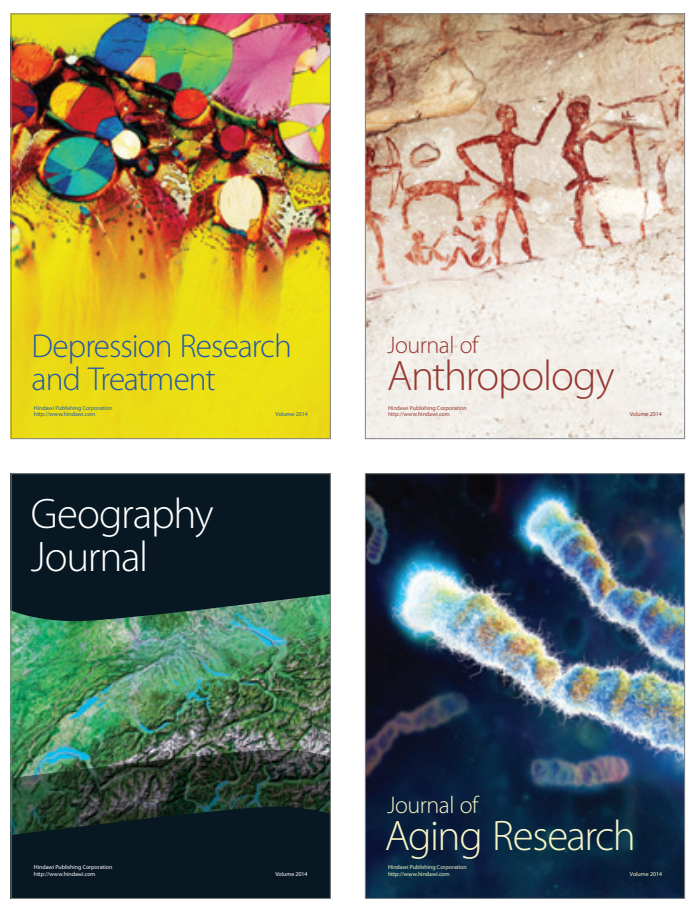
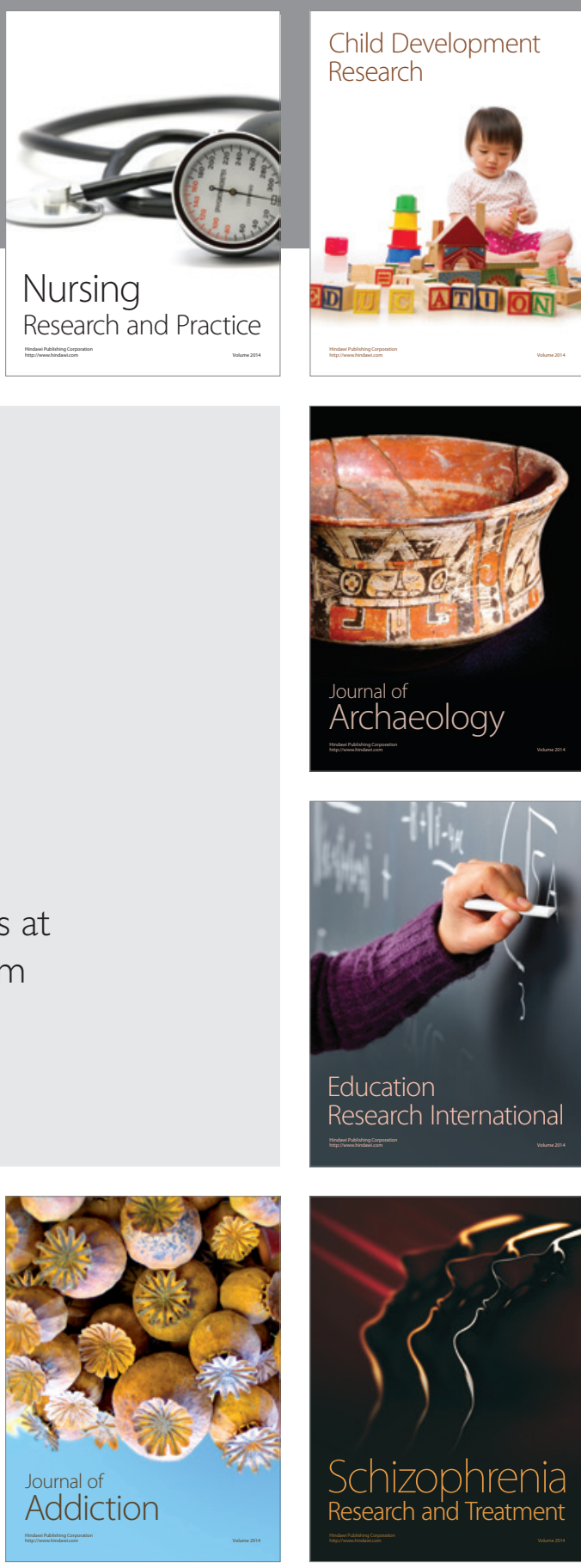

(D)
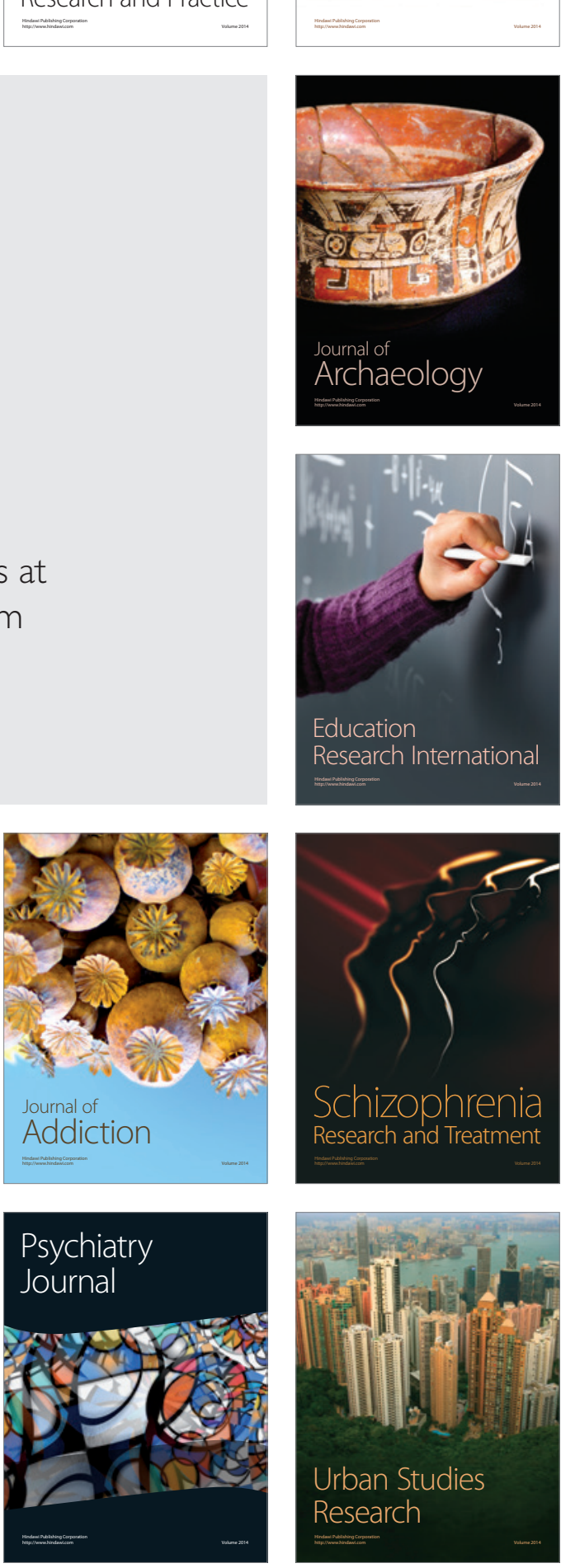